\title{
Determinants of MENA Countries participation in Global Value Chains
}

\author{
Hebatallah A. Soliman \\ Assistant Professor of \\ Economic \\ Faculty of Business \\ Adminstration \\ Sinai University
}

\author{
Reem M. Elbolok \\ Assistant Professor of \\ Management \\ Faculty of Business \\ Administration \\ Sinai University
}

\begin{abstract}
This study seeks to measure the effect of Macroeconomic factors which are GDP, FDI, Level of industrialization, Domestic Credit, Quality of infrastructure, Governance Indicators, along with property protection, and Innovations on the value of GVCs participation. By employing OLS model with panel fixed effects covering 15 MENA countries, over the period 2007-2018 for each country.

Consistent with our predictions, the empirical results indicate a positive relationship with GDP and FDI, while negative relationship with the level of industrialization, and find no association with Domestic credit. Concerning the impact of Infrastructure quality, we find a positive impact for use of mobile and Internet, and insignificant for quality port and quality roads. Concerning the impact of Governance Indicators, we find a positive impact for regulation quality and a negative impact for political stability, and control corruption and insignificant for rule of law. Our analysis also shows a positive impact for innovation and a negative impact for property protection.
\end{abstract}


This requires Attracting more foreign investment and directing it towards manufacturing industries, increasing the value added of manufacturing in the GDP, establish policies that encourage education, technical training, and development Human capital to the needs of the specific value chain segments, specialized skills are a needed for participation in high value added stages of the chain, encouraging innovation, increasing the efforts to reforms Trade and investment policy, as well as improvements of infrastructure, logistics, institutions quality, protecting intellectual property rights, and Improvement the role of banks to promoting investments.

This study adds value for how macroeconomic factors and corporate governance work as a motivator or constrained for GVCs participation in different markets.

Keywords: Global Value Chains, MENA Countries, level of development, Quality of Institutions, Macroeconomic factors, Innovation, property protection, Quality of infrastructure, Governance Indicators, level of industrialization.

\section{محددات مشاركة دول الثرق الأوسط وشمال إفريقيا في سلاسل القيمة العالمية الأطية}

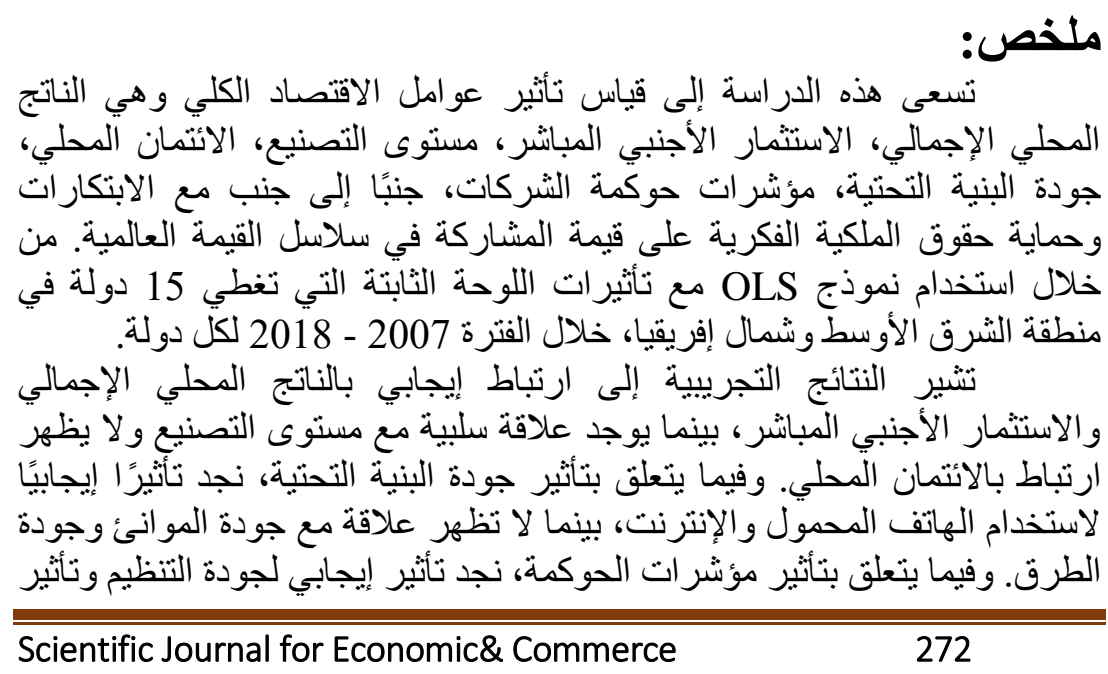




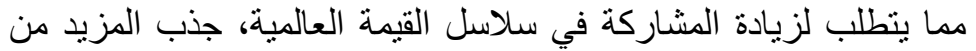

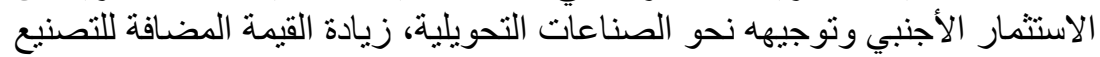

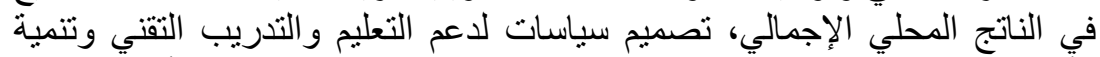

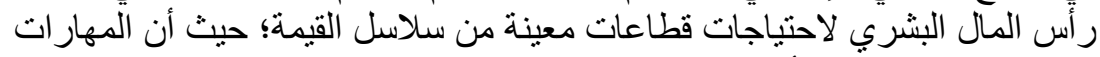

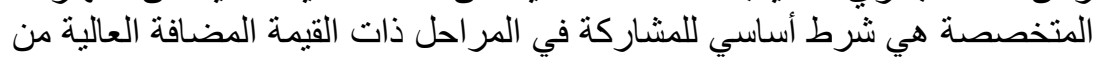

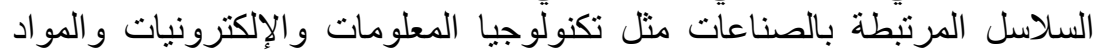

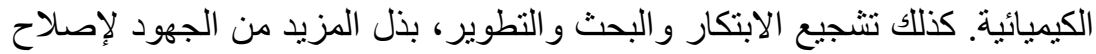

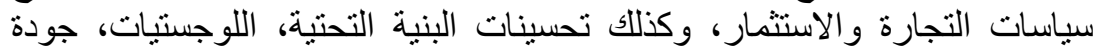

المؤسسات، حماية حقوق الملكية الفكرية، وكذللك تعزيز دور البناتية البنوك في منح المزيد

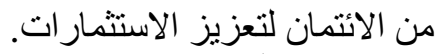

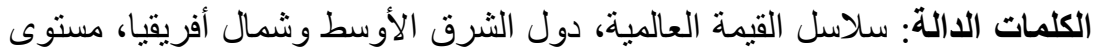

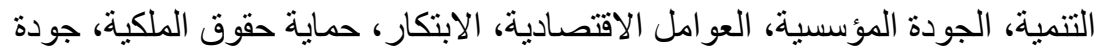

البنية التحتية، البحث و التطوير، لمستو ملتوى التصنيع.

\section{1- Introduction}

Global Value Chains (GVCs) represent the principal division of labor extended to a worldwide scale. In GVCs manufacture of products and services takes place by breaking up the manufacture process into small portions, each of which takes place in many countries. (World Bank, 2020) The idea of the division of labor in a single place is very old think of Adam Smith's pin factory in 1776 (Ramesh, 2004) and where each worker did a different task. Value is added in every task, but they're still all organized in one place, or at least all the raw materials are brought to this place where everything else happens.

Now over the past decades, this type of division of labor has become global, GVCs expanded as a result of advancement in transportation, information, and communications technology such as container ships, modern logistics, E-commerce, data flows, telecommunications and, the internet, along with the 
removal of trade and investment barriers, implying that the label of Made in Country X has no value for products made anywhere in the World. (Richard, 2020) the activity which defines GVCs is sometimes called trading in tasks, suggest that the production stages are divide, with companies specializing in a particular task and stage of production rather than producing the entire product depending on where each step can be done most efficiently. (De Melo J. and Twum A.,2020), this international division of labor is not limited to the physical production; activities such as research and development, design, assembly, marketing, and post-sale service are all necessary to bring goods to the market. Most of those activities look more like services than like goods but there are all parts of the value chain and they can all be placed in different countries.

This change enabled economic convergence, allowing low-income countries to catch up with high-income countries. (World Bank, 2020) where it can be observed through increased expansion into emerging and developing economies. One of the major determinants of some developing countries' convergence with high-income countries is their ability to attract GVCs. (Hausmann, 2014).

The division of tasks and business activities may have given some developing country firms and employees the opportunity to compete in the global economy without having to create a full product or value chain (Stamm, 2004; Baldwin, 2012; Escaith, 2014; OECD, 2013, Kummritz et al. 2017, Mouanda G. and Gong J., 2019) At the same time, many developing countries are confronted by many challenges for consolidation into GVCs which include, development of human capital through ongoing education and adequate training, developing infrastructure, improving capital availability, Create an appropriate environment to attract foreign direct investment, and scaling up the quality of organizations (OECD, 2013; Bamber et al., 2014). The occurrence of GVCs has resurrected some tough debates about the role that governments can play in stimulating more outcomes through trade and investment policy 
or industrial policy. (UNCTAD, 2014) So we focus in this study on documents key stylized facts about MENA GVCs participation, and then assesses which factors and policies encourage higher GVCs participation in MENA countries.

The road map of this study is as follows: section 2 GVCs concept and MENA countries participation, section 3 the importance of GVCs and main determinants of participation, section 4 literature, section 5 Research hypotheses, section 6 describes the methodology, section 7 Conclusions and recommendations.

\section{2- GVCs Concept and MENA Countries Participation}

A global value chains (GVCs) is a network of interconnected stages for the production of products and services that extend across international boundaries. Naturally, a GVCs combines imported intermediate goods with domestic goods and services to create products that are then exported for use as intermediates in the next stages of production. standard GVCs contain several production stage of production from product creation to assembly, branding, and marketing. (Kevin, et al., 2015). Sachs, 1998 defines GVCs as "different stages of the production process of a single output can be carried out in different parts of the world, depending on the comparative advantages of alternative production sites" (Sachs, 1998).

While global value chains have existed for centuries their fastest growth was in the 1990s and 2000s. Between 1990 and 2008 global value chain trade grew by $25 \%$ from $41 \%$ to $52 \%$ that is 2 times faster than the previous 20 years. (World Bank, 2020) Figure (1) GVCs participation by major geographic regions, from 1990 to 2018, there was a steady rise in global GVC participation. However, following the financial crisis of 2008 overall trade growth was slow and GVCs trade contracted between 2009 and 2015. At the time of the crisis, world trade 
decrease more sharply than GDP, and the investments required to stimulate GVCs dried up (World Bank, 2020). In spite of the latest decrease in GVCs contribution, all societies have improved GVCs participation between 1990-2018, with Europe and Central Asia recording the chief growth in participation. East Asia\& Pacific, has a relatively high participation rate, then North America, Latin America, South Asia, Middle East\& North Africa, and finally Sub-Saharan Africa. (UNCTAD, 2019)

Fig (1): GVC participation by Region 1990-2018

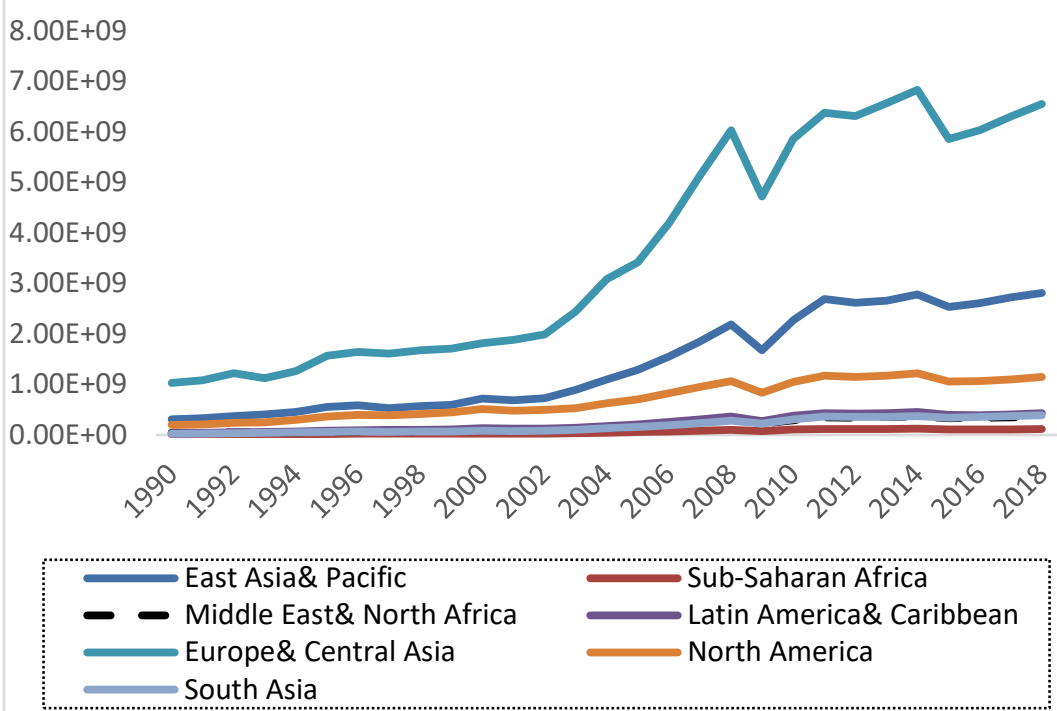

Source: UNCTAD-Eora Global Value Chain Database, https://worldmrio.com/unctadgvc/.

Figure (2) represents MENA GVCs participation by member state shows that Saudi Arabia has the highest volume followed by Israel, United Arab Emirate, Iran, Algeria, and Kuwait. While, Qatar, Morocco, Iraq, Oman, Egypt have med value. while, Tunis, Syria, Bahrain, Jordan, Lebanon, Malta, Djibouti have the lowest value of GVCs.(UNCTAD,2019)

There are many different ways in which countries participate in global value chains. Some contribute by selling raw materials or parts to other countries, which then include these imports into their own manufacture for exporting them later, we say these countries engage in forward participation, 
for example, a farm producing and exporting cotton to be turned into cloth in another country. Other countries import parts and components from abroad to be used in their own exports (Foreign value added), we say these countries engage in backward participation, for example, a plant importing clothes for further processing and exports. In the same sense, it is also an indicator of how much hypothetical "desolation" to GVCs would happen if a country's exports were blocked, it represents the response of the GVCs to shocks in the respective country. (De Melo J. and Twum A., 2020)

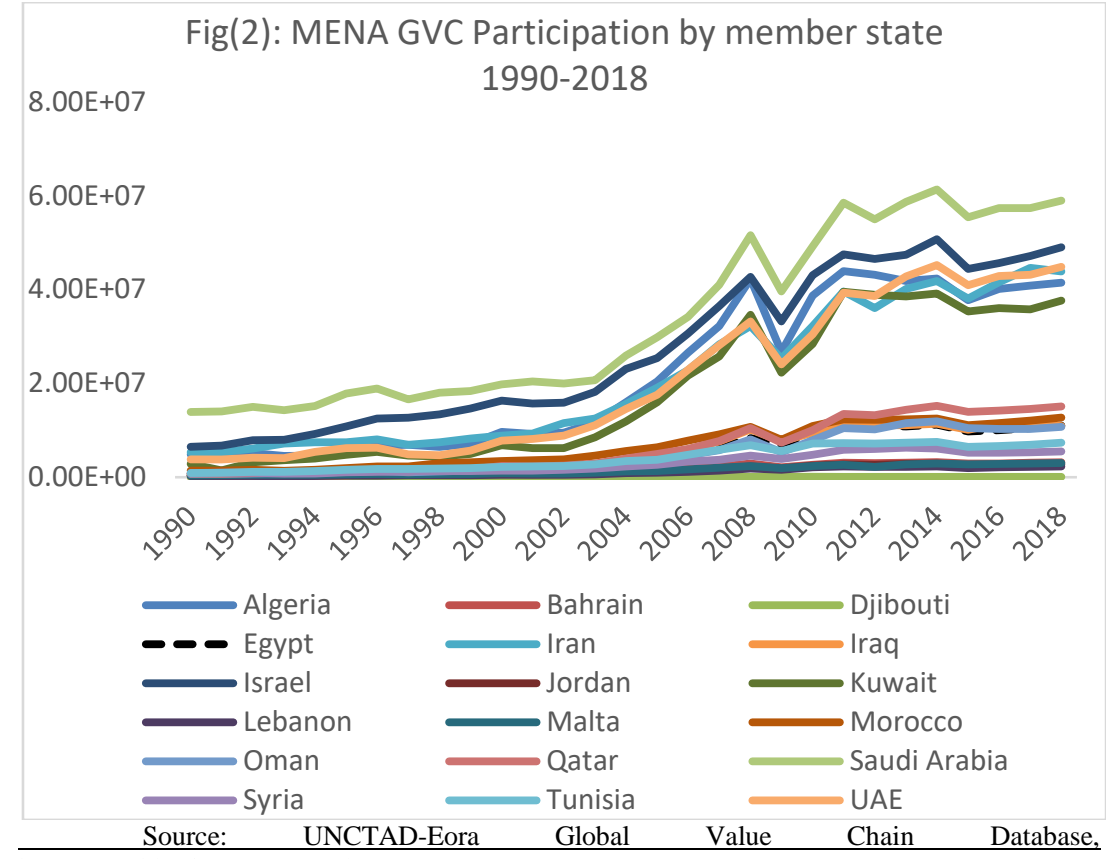

https://worldmrio.com/unctadgvc/.

Figure (3) shows that Europe\& Central Asia as well as East Asia \& pacific have the largest shares of foreign value added in trade, with manufacturing industries accounting for a large portion of exports. In Latin America, South Asia, the Middle East \& North Africa and, sub-Saharan Africa, the foreign value added in exports is much lower, where natural 
resources and commodities exports with slight external tend to play a vital role.

Figure (4) show Forward participation refers to the portion of exports that is produced in the region. It calculates how much a country's trade contributes to its GDP. We observe that forward participation (mostly selling intermediates for further processing) of MENA countries and Sub-Sahara Africa more than backward participation (concentrated in importing foreign intermediates). This is to be anticipated, given that these countries depend heavily on raw material exports, accounting for $40 \%$ of total exports in 2018. These raw materials (natural resources) are shipped to other countries to be used in the manufacture of higher value-added. (de Melo \& Twum.,2020)

Fig (3): Backword Participation GVC by reagon

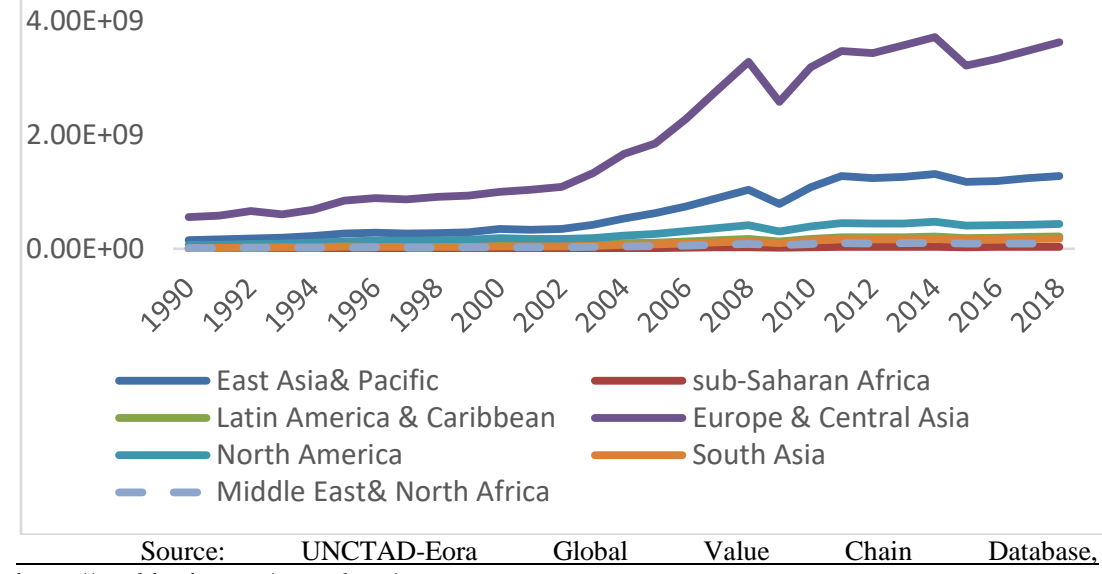
https://worldmrio.com/unctadgvc/. 


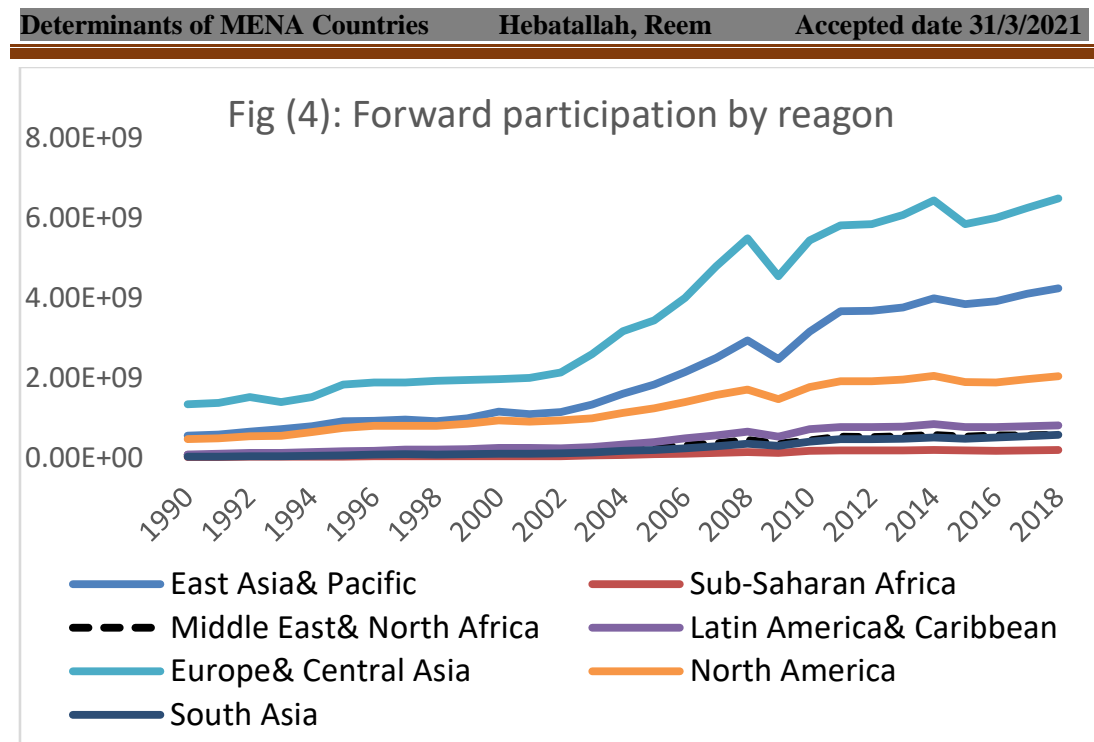

Source: UNCTAD-Eora Global Value Chain Database, https://worldmrio.com/unctadgvc/.

The backward and forward participation indicators, which calculate the degree of integration in GVCs, are highly depends on the types of goods exchanged. For example, natural resource-rich countries, such as those in the MENA countries, have a higher domestic value added share in their exports because extractive industries are less dependent on foreign value added. the manufacturing sectors with low value added activities have seen the most growth in backward participation especially in "light manufacturing", manufacturing machinery, transport equipment, and electrical equipment. While forward participation has been in agriculture, Mining, Petroleum, and Chemical Products. (see For each country/sector of exports, 1990 - 2017, Global Value Chain ,https://worldmrio.com/unctadgvc/) The region has so far been unable to completely integrate into global production networks, remaining a minor player on the global level. (Davide et al., 2016)

Now 2020, global economy face COVID-19 pandemic. which having an extra ordinary influence on progress around the world. As governments impose social separation practices and 
close non-essential businesses to reduce the speed of the spread of the virus, industrial, mining, and certain service sectors are possible to faces greater instant supply-side shocks relative to demand-side shocks. while its labor force is unable to work from their homes.( R. Maria et al., 2020, Inoue H. and Todo Y, 2020).

The implementation and expansion of tariff and nontariff procedures in the form of new health and safety standards requirments will leads to major disruption to supply chains, will compromise countries' access to critical goods or services, and is likely to result in higher trade costs.(WTO, 2019) Growing isolationism may hamper the advancement of worldwide value chains, reducing the competitiveness of national manufacturers involved in complex global production networks and threatening the growth prospects of many middle and low-income countries.(Rincon, et al., 2020)

\section{3- The Importance of GVCs For Economic Development}

Developing countries faced a tough choice under the earlier model of industrialization. They could either try to create the entire manufacturing process of a complex good like the Vehicles, which could be very expensive and inefficient, or they can give up manufacturing and just remain specialized in agriculture or mining. Now, with GVCs it's likely to go into the value chain by undertaking one task, or a little task which is much easier than create the entire value chain. Baldwin and Yan, 2014 indicates that joining GVCs brings optimistic and important advances in productivity. First, multi-specialization breaking up the entire production processes of multipart products like vehicles and computers permits firms to specialize in the production of simple slices and tasks. Specializing allows firms to produce at scale with high productivity gains. Second, durable firm-to-firm relationships; Since for production the buyer often requires customized parts and components from its suppliers. All of these characteristics increase technology and 
knowledge transmission as well as capital access, allowing firms to promote productivity and income and makes GVCs trade more controlling than old-style trade in promoting development, and poverty decline.(Carlo and Roberta,2011, World Bank, 2020)

(Baldwin and Yan 2014) discovered that, Canadian companies gained a 5\% productivity advantage in the first year after participate into a GVCs, with the productivity advantage adding to $9 \%$ four years later. On the other side, firms that withdrew from a GVCs lost $1 \%$ of their output in the first year and $8 \%$ over a four-year period.

\section{3-1 The Determinants Of GVCs Participation}

The WTO-OECD (2013), WTO (2014) notes, countryspecific determining factors such as a positive business environment, labor skills, and better infrastructure are favorable to GVCs participation. They identify tariffs, restricted access to trade funding, standards compliance, and other trade obstacles as impeding GVCs participation. Similarly, (Hummels et al., 2012) discovered that improved transportation infrastructure and an encouraging business environment have a positive influence on trade. (Kevin, et al, 2015)

World Bank, 2020 emphasize on three kinds of subsidizing: (a) natural resources, (b) employment, which includes low, middle, and high-skilled, as well as (c) funds or financial resources. having plenty of natural resources are a pushing force for future GVCs participation, but not for backward GVCs participation.

Geography: Due to geography and distance, trade costs will influence which countries to import goods from and how a country's is positioned in GVCs. The proximity of Vietnam to regional electronics inputs suppliers such as China, Japan, Korea, and Singapore clearly aided its involvement in the 
electronics sector. Likewise, Morocco took advantage of its proximity to the EU markets to become Africa's largest passenger vehicles manufacturer in 2017. Because of the importance of geography in determining GVCs participation, for the developing countries, can promote GVCs participation by development transportation and communication infrastructure as well as the regulatory framework.

Institutional quality: Contractual compliance is a major stumbling block to conventional trade flows, and GVCs are particularly sensitive to the contractual institutions' efficiency, due to its strong firm-to-firm interactions.

Level of development and degree of industrialization: the structure of the economy is possible to vary along the development pathway and such changes can be revealed in GVC participation proportions. For example, countries at the primary stage of economic growth be likely to specialize in principal products which work as inputs or raw materials in manufacturing processes (e.g. agriculture or organic resource extraction) enhancing principally the potential for future participation.

Openness to FDI: FDI acts as a channel for GVC participation, bringing international capital and technical expertise, it is anticipated that FDI will be closely related to the form of GVC participation. FDI inward to natural resource for example can foster forward GVCs linkages. FDI inward for Manufacturing and export processing facility can enhance backward relationships (see Hummels, 2001; Miroudot and Ragoussis, 2009).

Market size: According to the gravity theory of trade, trade volumes are positively proportional to the economic mass of trading partners and negatively proportional to the distance between them. (Anderson, 1979; Evenett and Keller, 2002; Anderson and van Wincoop, 2003, Hebatallah A. Soliman, 2020). Is expected that market size important determinant of the volume of GVCs trade in the case of gross trade. However, when we think about the indices of backward and forward 
GVCs integration, the perspective changes. Larger countries have a larger industrial capacity, which reduces the use of imported inputs comparison to locally sourced inputs, lowering the GVCb, and the higher the GVCf participation.

\section{4- Literature}

There are relatively limited empirical studies dealing with factors that determine the countries' participation in GVCs. To our knowledge, the early evidence comes with Kowalski et al. (2015). The researchers use a cluster of 57 nations over 22 years. They find out the determinants that affect negatively (tariffs, distance to the closest manufacturing hub, and GDP) and positively (FDI, level of industrialization) in backward participation, but in forward the determinants that affect negatively (tariffs, and level of industrialization) and positively with GDP.

In the same vein, Kevin Cheng et al. (2015) They find out tariffs, and investment \& trade restrictiveness affects negatively the engagement in GVCs in both high-tech and lowtech manufacturing, the impact of real GDP positively effects on high-tech and negatively effect in low-tech manufacturing, infrastructure, and human capital development positively effect in both high and low tech manufacturing. Institutions and labor regulation positively effect in both high and low-tech manufacturing, Also, it is shown that distance to final demand and economic complex index impacts positively the involvement in GVCs.

Lopez-Gonzalez (2016) employs a sample of developed and emerging economies to investigate the determinants of domestic value-added in exports. Find out, On the whole, capital labor ratio, skill intensity, output per worker, FDI, foreign value add in industry exports, and domestic demand as drivers to GVC participation. Nevertheless, tariffs and distance to economic activity are essential obstacles. In developed countries skill 
intensity, productivity per worker, FDI, foreign value added in industry exports domestic demand are positively associated with GVC participation, in emerging countries capital labor ratio, foreign value add in industry exports, and domestic demand are positively associated with GVC participation. Rule of law, tariffs, and distance to economic activity are negatively associated with GVC participation.

Similarly, Allard et al. (2016) study the determinants of foreign value added. They use an unbalanced panel data for 185 countries. The results show that real GDP per capita, domestic credit to the private sector, education, rule of law, and quality of infrastructure promote Foreign value add. By contrast, tariffs, and GDP impact negatively and significantly foreign valueadded.

Tinta A. (2017) emphases on African countries, Using a gravity model with fixed effects panels, The results show that the level of industrlizaton, domestic value add per capita, per capita GDP negatively associated with GVC backward, intracommunity trade, FDI, merchandise trade, and tariffs influence positively. in forward, the level of industrialization, per capita domestic value add, per capita GDP positively associated but inter-community trade, trade complementary index, tariffs, merchandise diversification index, the similarity in merchandise trade and FDI negatively associated.

Mouanda G. and Gong J. (2019), aims to examine the factors influencing the participation in GVCs for 17 landlocked countries African and Non-African countries by Use OLS. they find out in African countries the determinants that affect negatively in forward linkage (tariffs, Institutional quality, Access to domestic credit, level of industrialization and skill intensity) and positively (FDI, quality of overall infrastructure, domestic market size), and all variables negatively effect in backward linkage. But in non-African countries, they find out in forward linkage the determinants that affect negatively tariffs, Institutional quality, Access to domestic credit, and positively with FDI, quality of overall infrastructure, level of 
industrialization, skill intensity and productivity of worker. In backward linkage find out negatively with Institutional quality, domestic market size, and skill intensity. and positively with FDI, Access to domestic credit, productivity per worker.

de Melo J. and Twum A. (2020), focus on 149 countries over the period 1995-2015, use OLS. Find out increase in tariffs on intermediate imports and exports, as well as trade costs, are negatively correlated with overall GVC participation. Forward GVC, is positively associated with GDP, and negatively with manufacturing value add, FDI stock, and trade cost. Backward GVC participation is positively associated with manufacturing value add, FDI stock, and the number of mobile phone subscribers, and negatively with GDP and trade tariffs.

From the previous literature, to our knowledge, there is little studies focus on MENA countries so our study focus on MENA countries to determine the key factors which promote the participation in GVCs over the period 20072018 By employing OLS model with panel fixed effects with using different variables such as Quality of infrasrtucture Represented in (Quality of ports, Quality of roads), improvements in technology Represented in (number of mobile phone subscribers, individuals using the internet) innovation index, property protection, quality of institutions Represented in (political stability, control of corruption, rule of law, regulatory quality)

\section{5- Research hypotheses}

H1: The GVC forward (GVCf) and GVC backward (GVCb) is positively associated with GDP.

H2: The Manufacturing share in GDP is positively associated with GVCf, and GVCb.

H3: FDI stock is positively associated with GVCf, and GVCb. H4: The GVCf, and GVCb is positively associated with access to domestic credit. 
H5: The GVCf, and GVCb is positively associated with the Quality of Infrastructure.

H6: The GVCf, and GVCb is positively associated with the Quality of Institutions.

H7: The GVCf, and GVCb is positively associated with high Innovation.

\section{6- Methodology}

Econometric models, which are estimating the determinants of Global value chains participation, mainly are multivariate regression models. Our empirical strategy relies on panel ordinary least square with fixed effects as suggested in the literature. where Panel data helps to reach closer and more accurate results where data is combined from temporal and cross-sectional trends, and also controls individual heterogeneity. As it assumes that country data is not homogeneous, it also provides more useful information, and less collinearity between the variables. (Baltagi, 2005). According to the empirical studies, our model specification is based on papers dealing with factors that affect countries' participation in GVCs (see Kevin Cheng et al., 2015; Kowalski et al., 2015; Lopez-Gonzalez, 2016; Tinta, 2017, Mouanda G. and Gong J., 2019, de Melo J. and Twum A. 2020). To do so, we regress the dependent variable on a set of explication variables as follows:

$$
\begin{aligned}
\ln G V C f_{i t}= & a_{0}+a_{1} \ln G D P_{i t}+a_{2} \ln M V A_{i t} \\
& +a_{3} \ln F D I_{i t}+D C_{\mathrm{it}}+Q P_{\mathrm{it}}+Q R_{\mathrm{it}} \\
& +\ln M o b i_{i t}+U I_{\mathrm{it}}+I N_{\mathrm{it}}+P P_{\mathrm{it}}+P S_{\mathrm{it}} \\
& +C C_{\mathrm{it}}+R L_{\mathrm{it}}+R Q_{\mathrm{it}}+\varepsilon_{\mathrm{it}} \\
\mathrm{I}= & =1, . ., 15 ; \quad \mathrm{t}=2007, . ., 2018 .
\end{aligned}
$$

Where $G V C f_{\text {it }}$ is the GVC forwardas, and we use this equation another time with $G V C b_{\text {it }}$ is GVC backward, dependent variables, FDI FDI stock, GDP Gross Domestic Products, $M V A$ 
Manufacturing share in GDP, $D C$ domestic credit to the private sector by banks (\% of GDP), $Q P$ Quality of ports index, $Q R$ Quality of roads index, Mobi number of mobile phone subscribers (per 100 people), UI individuals using the internet (\% of population), IN innovation index, $P P$ property protection index, $P S$ Political Stability, $C C$ control of corruption, $R L$ rule of law), $R Q$ regulatory quality. $\varepsilon_{\text {it }}$ is the error term, Letter "L" indicate that the variables are expressed in natural logarithms.

\begin{tabular}{|c|c|c|c|c|}
\hline Variables & Symbol & Measure & $\begin{array}{l}\text { Expected } \\
\text { sign }\end{array}$ & Source \\
\hline $\begin{array}{l}\text { Global value chain backward } \\
\text { Global value chain forward }\end{array}$ & $\begin{array}{l}\text { GVCb } \\
\text { GVCf }\end{array}$ & $\begin{array}{c}\text { Values are in current year } \\
\text { '000 USD }\end{array}$ & & $\begin{array}{l}\text { UNCTAD-Eora Global } \\
\text { Value Chain Database }\end{array}$ \\
\hline Manufacturing & Mva & $\begin{array}{l}\text { Manufacturing, value added } \\
\text { (\% of GDP) }\end{array}$ & $\begin{array}{l}-\mathrm{GVCb} \\
+\mathrm{GVCf}\end{array}$ & WBI \\
\hline Foreign direct investment & FDI & FDI inflow stock & + & $\begin{array}{l}\text { UNCTAD trade } \\
\text { statistics }\end{array}$ \\
\hline Domestic credit & $\mathrm{DC}$ & $\begin{array}{l}\text { Domestic credit to private } \\
\text { sector by banks ( } \% \text { of GDP) }\end{array}$ & + & WBI \\
\hline Use internet & UI & $\begin{array}{l}\text { Individuals using the } \\
\text { Internet ( } \% \text { of population) }\end{array}$ & + & WBI \\
\hline Mobile cellular & Mobi & $\begin{array}{c}\text { Mobile cellular } \\
\text { subscriptions (per } 100 \\
\text { people) }\end{array}$ & + & WBI \\
\hline Quality ports & QP & $\begin{array}{l}\text { Quality of ports } \\
\text { infrastructure (1-7) }\end{array}$ & + & WBI \\
\hline Quality roads & QR & Quality of roads (1-7) & + & WBI \\
\hline property protection & PP & $\begin{array}{l}\text { Intellectual property } \\
\text { protection }(1-7)\end{array}$ & + & WBI \\
\hline Political stability & PS & $\begin{array}{c}\text { Political Stability and } \\
\text { Absence of } \\
\text { Violence/Terrorism(-2.5- } \\
\text { 2.5) }\end{array}$ & + & WBI \\
\hline Rule of low & RL & Rule of Law(-2.5-2.5) & + & WBI \\
\hline Regulatory quality & RQ & Regulatory quality(-2.5-2.5) & + & WBI \\
\hline Control of corruption & $\mathrm{CC}$ & $\begin{array}{c}\text { Control of corruption }(-2.5- \\
2.5)\end{array}$ & + & WBI \\
\hline
\end{tabular}




\section{6-1 Data, and Descriptive statistics}

Our analysis includes 15 MENA countries which are Algeria, Bahrain, Egypt, Iran, Iraq, Israel, Jordan, Kuwait, Lebanon, Morocco, Oman, Qatar, Saudi Arabia, Tunis, United Arab Emirate. and the data used for the estimation cover the period 2007-2018 for each country, The reason for using this period is the availability of time series data for all variables during this period for all countries. Such as the index of the quality of ports, as well as the index of innovation.

In accordance with the literature, the explanatory variables can be divided into three main groups The first group is about Macro factors, and for the need of this study we have selected: domestic market size, industrialization level, foreign direct investment, and access to domestic credit. the second group trade facilitation and the third group innovation.

We observe from table (1) descriptive statistics, the average of manufacturing value add in GDP, and the average quality of institutions is relatively low, but the average quality of infrastructure is relatively high that mean infrastructure play a vital role in GVC participation, Innovation, average of domestic credit and FDI relatively high that means Innovation, financial development, and FDI may improve GVC participation. 
Table (1): descriptive statistics

\begin{tabular}{|c|c|c|c|c|}
\hline VARIABLES & MEAN & Std. Dev. & MIN & MAX \\
\hline GVCf & 16.9 & 1.05 & 14.78 & 18.41 \\
\hline GVCb & 15.1 & 1.03 & 13.4 & 17.14 \\
\hline GDP & 26.3 & 0.97 & 24.62 & 28.17 \\
\hline FDI & 10.55 & 0.82 & 6.85 & 12.35 \\
\hline DC & 57.61 & 20.59 & 12.77 & 105.18 \\
\hline MVA & 17.45 & 12.26 & 4.42 & 65.01 \\
\hline IN & 3.52 & 0.8 & 2.09 & 5.8 \\
\hline UI & 54.18 & 23.53 & 9.45 & 100 \\
\hline Mobi & 4.75 & 0.32 & 3.65 & 5.36 \\
\hline QR & 4.58 & 1.04 & 2.65 & 6.65 \\
\hline QP & 4.57 & 0.85 & 2.7 & 6.5 \\
\hline PP & 4.22 & 0.97 & 1.82 & 5.98 \\
\hline PS & -0.37 & 0.84 & -1.7 & 1.22 \\
\hline$R L$ & 0.12 & 0.57 & -1.06 & 1.16 \\
\hline CC & 0.08 & 0.63 & -1.04 & 1.57 \\
\hline$R Q$ & 0.08 & 0.68 & -1.52 & 1.32 \\
\hline
\end{tabular}

The dependent variables:

- Backward GVC participation (GVCb): measures the share of country $s$ ' exports that include Foreign value add.

- Forward GVC participation (GVCf): measures the share of a country's exports that include Domestic value add.

\section{The explanatory variables}

Level of Development: we use GDP as the proxy for market size. the combined forward and backward engagement increase as GDP increase. (Kowalski P., et al., 2015). The following hypothesis was formulated to test the GDP: H1: The GVCf and GVCb is positively associated with GDP.

Manufacturing share in GDP: The higher the manufacturing sector share in GDP, the greater the forward, and backward participation. (Kowalski P., et al., 2015). The following hypothesis was formulated to test the Manufacturing 

positively associated with GVCf, and GVCb.

FDI: Trade and investment are inextricably linked. huge cross-border investments in extractive industries by globally operating transnational corporations (TNCs) are driving natural resources trade. The relationship between FDI stock and GVC participation rates in countries is strong, and growing over time, especially in the poorest countries, indicating that FDI could be an important opportunity for less developed countries to gain access to GVCs and increase their contribution. (UNCTAD, 2013). following hypothesis was formulated to test the FDI stock:

H3: FDI stock is positively associated with GVCb and GVCf.

Access to domestic credit: improve access to banks leads to improve participation in GVCs. World Bank 2020. Access to funding has been a vital factor in trade and specialization (Chor, 2010; Kowalski, 2011) and will almost certainly play a key role GVC participation. following hypothesis was formulated to test the access to domestic credit: H4: The GVCf and GVCb is positively associated with access to domestic credit.

Trade facilitation: The quality of infrastructure and the institutions are expected to have a significant effect on GVC integration. technological development and remove trade barriers stimulated manufacturers to expand production processes beyond national borders (World Bank, 2020). we use two key basic infrastructure sectors: communication, and transportation network. Quality of port, quality of roads, to represent transportation. Internet users (\% of the population) and Mobile cellular subscriptions (per 100 people) to represent the communication sector.

Institutional quality is highly correlated with trade. Levchenko (2007), Costinot (2009) indicates that good institutions can be a 
significant determinant of trade performance in industries with high levels of task complexity. according to the findings of Nunn (2007), strong contract compliance is especially important for export performance and can be significant source of comparative advantage. World Bank (2020) indicates that political stability; quality of regulations; regulation of law; control of corruption, and Intellectual property rights protection lead to improve participation in GVCs. following hypothesis was formulated to test the Trade facilitation: H5: The GVCf, and GVCb is positively associated with the Quality of Infrastructure.

H6: The GVCf, and GVCb is positively associated with the Quality of Institutions.

Innovation: participating in GVCs, according to Hausmann (2014), is a way of learning by doing that allows for the accumulation of productive skills that are requiried to enter the market. As a result, focusing on learning and continuous training may be an effective positive strategy that the government could follow to assist GVC participation. Research and development (R\&D) an important source of create an intellectual property, and expected they are play a role in determining the form of value chain. Countries should invest in human resources capital to improve domestic capacity and promote value chain promotion. Malysia's Penang Skills Development Centre has been instrumental in assist electronic engineering GVCs in the country. World Bank (2020). following hypothesis was formulated to test the Innovation H7: The GVCf, and GVCb is positively associated with high Innovation 


\section{6-2 Panel unit root test results}

In order to analyse the relationships among the variables, unit root and OLS methods are applied to the balanced data set. Employing Levin, Lin\&Chu t-stat, Im Peseran and Shin (2003) and Fisher ADF unit root test. The results of the unit root test are showen in Table (2), we discovered that all of the series was level stationary based on the test results.

Table (2): Panel unit root tests results in level

\begin{tabular}{|c|c|c|c|c|}
\hline & LLC & IPS & ADF-fisher & PP- fisher \\
\hline Gvcb & $-13.04 *$ & $-7.03^{*}$ & $108.9^{*}$ & $62.70^{*}$ \\
\hline Gvcf & $-4.083^{*}$ & $-2.799 *$ & $52.72 *$ & $63.927 *$ \\
\hline Gdp & $-4.302^{*}$ & -0.571 & 35.192 & $39.96^{* * *}$ \\
\hline Fdi & $-13.813^{*}$ & $-5.291^{*}$ & $83.74 *$ & $79.37^{*}$ \\
\hline Dc & $-4.826^{*}$ & 0.238 & $39.338 * *$ & $48.868^{* *}$ \\
\hline Mva & $-3.93 *$ & $-2.11^{* *}$ & $55.61^{*}$ & $52.92 *$ \\
\hline $\mathbf{U i}$ & $-2.620 *$ & 0.611 & $42.59 * * *$ & $54.33^{*}$ \\
\hline Mobi & $-7.31 *$ & $-3.26^{*}$ & $60.25^{*}$ & $111.6^{*}$ \\
\hline Qr & $-7.37 *$ & $-1.28^{* * *}$ & $38.42 * * *$ & $39.85^{* * *}$ \\
\hline Qp & $-19.62^{*}$ & $-1.71 * *$ & $38.12 * * *$ & $31.37 * * *$ \\
\hline in & $-4.827 *$ & 0.554 & 25.68 & $45.92^{* *}$ \\
\hline Pstab & $-3.61 *$ & $-1.23^{* * *}$ & $39.96 * * *$ & $45.03^{* *}$ \\
\hline Rlow & $-2.05 * *$ & $-1.74 * *$ & $41.75 * * *$ & $47.80^{* * *}$ \\
\hline Ccour & $-4.153^{*}$ & $-2.495^{*}$ & $49.282 * *$ & 30.551 \\
\hline $\mathbf{R q}$ & $-3.28 *$ & $-1.58^{* *}$ & $40.46^{* * *}$ & $43.54 * *$ \\
\hline pp & $-2.68 *$ & 0.955 & $34.99 * * *$ & 19.98 \\
\hline
\end{tabular}


Determinants of MENA Countries Hebatallah, Reem Accepted date 31/3/2021

Table (3) OLS results GVC forward, and bacword participation

\begin{tabular}{|c|c|c|c|c|}
\hline \multicolumn{5}{|c|}{ GVCf } \\
\hline & (1) & (2) & (3) & (4) \\
\hline variables & Coeff & Coeff & Coeff & Coeff \\
\hline Gdp & $\begin{array}{l}0.634 * \\
(0.072)\end{array}$ & $\begin{array}{l}0.586 * \\
(0.095)\end{array}$ & $\begin{array}{l}0.422^{*} \\
(0.082)\end{array}$ & $\begin{array}{l}0.721^{*} \\
(0.068)\end{array}$ \\
\hline Fdi & $\begin{array}{l}0.132 * \\
(0.029)\end{array}$ & $\begin{array}{l}0.193 * \\
(0.039)\end{array}$ & $\begin{array}{c}0.041 \\
(0.045)\end{array}$ & $\begin{array}{l}0.121 * \\
(0.026)\end{array}$ \\
\hline Dc & $\begin{array}{c}0.002^{* * * *} * \\
(0.010)\end{array}$ & $\begin{array}{l}0.0007 \\
(0.001)\end{array}$ & & $\begin{array}{c}0.0005 \\
(0.0009)\end{array}$ \\
\hline$M v a$ & $\begin{array}{c}-0.005^{* *} \\
(0.003)\end{array}$ & $\begin{array}{c}-0.007 * * \\
(0.173)\end{array}$ & $\begin{array}{c}-0.004 * * * \\
(0.002)\end{array}$ & $\begin{array}{c}-0.008 * \\
(0.002)\end{array}$ \\
\hline in & & $\begin{array}{c}0.128 * * \\
(0.049)\end{array}$ & $\begin{array}{c}0.099 * * \\
(0.047)\end{array}$ & \\
\hline$p p$ & & $\begin{array}{c}-0.084 * * \\
(0.038)\end{array}$ & $\begin{array}{c}-0.059 * * * \\
(0.034)\end{array}$ & \\
\hline Mobi & & & $\begin{array}{c}0.140 * * \\
(0.062)\end{array}$ & \\
\hline$u i$ & & & $\begin{array}{c}0.004 * \\
(0.0009)\end{array}$ & \\
\hline Qp & & & $\begin{array}{l}0.0041 \\
(0.041)\end{array}$ & \\
\hline $\mathrm{qr}$ & & & $\begin{array}{l}0.0159 \\
(0.036)\end{array}$ & \\
\hline Pstab & & & & $\begin{array}{c}-0.197 * \\
(0.038)\end{array}$ \\
\hline Rlow & & & & $\begin{array}{c}0.009 \\
(0.079)\end{array}$ \\
\hline CCour & & & & $\begin{array}{c}-0.183 * \\
(0.065)\end{array}$ \\
\hline $\mathrm{Rq}$ & & & & $\begin{array}{l}0.369^{*} \\
(0.070)\end{array}$ \\
\hline $\mathrm{C}$ & $\begin{array}{l}-1.213 \\
(1.790)\end{array}$ & $\begin{array}{l}-0.583 \\
(2.297)\end{array}$ & $\begin{array}{c}4.353 * * \\
(2.089)\end{array}$ & $\begin{array}{l}-3.352 * * \\
(1.7007)\end{array}$ \\
\hline Adj. $R^{2}$ & 0.987 & 0.988 & 0.99 & 0.99 \\
\hline F statistic & $\begin{array}{l}730.4 * \\
(0.000) \\
\end{array}$ & $\begin{array}{c}643.94 * \\
(0.000) \\
\end{array}$ & $\begin{array}{c}690.88^{*} \\
(0.000) \\
\end{array}$ & $\begin{array}{l}771.5^{*} \\
(0.000) \\
\end{array}$ \\
\hline Num. of Count & 15 & 15 & 15 & 15 \\
\hline Obs. & 169 & 169 & 169 & 169 \\
\hline
\end{tabular}


Determinants of MENA Countries $\quad$ Hebatallah, Reem Accepted date 31/3/2021

\begin{tabular}{|c|c|c|c|c|}
\hline \multicolumn{5}{|c|}{ GVCb } \\
\hline & $(5)$ & $(6)$ & $(7)$ & $(8)$ \\
\hline variables & Coeff & Coeff & Coeff & Coeff \\
\hline Gdp & $\begin{array}{l}0.460 * \\
(0.088)\end{array}$ & $\begin{array}{c}0.4148 * \\
(0.117)\end{array}$ & $\begin{array}{l}0.286^{*} \\
(0.104)\end{array}$ & $\begin{array}{l}0.580 * \\
(0.120)\end{array}$ \\
\hline Fdi & $\begin{array}{l}0.116 * \\
(0.036)\end{array}$ & $\begin{array}{l}0.173 * \\
(0.048)\end{array}$ & $\begin{array}{c}0.014 \\
(0.057)\end{array}$ & $\begin{array}{l}0.145^{*} \\
(0.046)\end{array}$ \\
\hline Dc & $\begin{array}{l}0.0009 \\
(0.001)\end{array}$ & $\begin{array}{c}-0.0006 \\
(0.001)\end{array}$ & & $\begin{array}{c}-0.0008 \\
(0.0014)\end{array}$ \\
\hline$M v a$ & $\begin{array}{c}-0.008 * * \\
(0.003)\end{array}$ & $\begin{array}{c}-0.010 * * \\
(0.003)\end{array}$ & $\begin{array}{c}-0.008 * * \\
(0.003)\end{array}$ & $\begin{array}{c}-0.012 * \\
(0.003)\end{array}$ \\
\hline in & & $\begin{array}{c}0.087 \\
(0.061)\end{array}$ & $\begin{array}{c}0.029 \\
(0.059)\end{array}$ & \\
\hline$p p$ & & $\begin{array}{c}-0.096 * * \\
(0.046)\end{array}$ & $\begin{array}{c}-0.088 * * \\
(0.043)\end{array}$ & $\begin{array}{c}-0.069 * * * \\
(0.039)\end{array}$ \\
\hline Mobi & & & $\begin{array}{c}0.176^{* *} \\
(0.078)\end{array}$ & \\
\hline$u i$ & & & $\begin{array}{c}0.002 * * \\
(0.001)\end{array}$ & \\
\hline Qp & & & $\begin{array}{c}0.0058 \\
(0.053)\end{array}$ & \\
\hline $\mathrm{qr}$ & & & $\begin{array}{c}0.100 * * \\
(0.045)\end{array}$ & \\
\hline Pstab & & & & $\begin{array}{c}-0.113^{* *} * \\
(0.061)\end{array}$ \\
\hline Rlow & & & & $\begin{array}{l}-0.060 \\
(0.111)\end{array}$ \\
\hline CCour & & & & $\begin{array}{c}-0.194 * * \\
(0.090)\end{array}$ \\
\hline $\mathrm{Rq}$ & & & & $\begin{array}{l}0.395 * \\
(0.098)\end{array}$ \\
\hline $\mathrm{C}$ & $\begin{array}{c}1.739 \\
(2.200)\end{array}$ & $\begin{array}{c}2.678 \\
(2.828)\end{array}$ & $\begin{array}{c}6.385^{* *} * \\
(2.627)\end{array}$ & $\begin{array}{c}-1.192 \\
(2.957)\end{array}$ \\
\hline Adj. $R^{2}$ & 0.981 & 0.98 & 0.98 & 0.98 \\
\hline F statistic & $\begin{array}{c}509 \\
(0.000)\end{array}$ & $\begin{array}{c}604 \\
(0.000)\end{array}$ & $\begin{array}{c}414.7 \\
(0.000)\end{array}$ & $\begin{array}{c}393 \\
(0.000)\end{array}$ \\
\hline Num. of & & 15 & & \\
\hline Count & 15 & & 15 & 15 \\
\hline Obs. & 169 & 169 & 169 & 169 \\
\hline
\end{tabular}


When testing resid unit root, it was found stationary at level. Which means that the models do not have problems. And the results are as follow.

Table (4): Resid unit root tests results in level

\begin{tabular}{|c|c|c|}
\hline F-ADF-test & IPS-test & LLC-test \\
\hline \multicolumn{3}{|c|}{ (1) } \\
\hline 70.197* & $-3.829 *$ & $-6.631^{*}$ \\
\hline \multicolumn{3}{|c|}{ (2) } \\
\hline $100.70^{*}$ & $-8.244 *$ & $-10.072 *$ \\
\hline \multicolumn{3}{|c|}{ (3) } \\
\hline 71.048* & $-4.572 *$ & $-9.024 *$ \\
\hline \multicolumn{3}{|c|}{ (4) } \\
\hline $70.36^{*}$ & $-4.026^{*}$ & $-6.751 *$ \\
\hline \multicolumn{3}{|c|}{ (5) } \\
\hline 68.94* & $-4.246^{*}$ & $-7.432^{*}$ \\
\hline \multicolumn{3}{|c|}{ (6) } \\
\hline $64.12 *$ & $-3.757^{*}$ & $-8.140 *$ \\
\hline \multicolumn{3}{|c|}{ (7) } \\
\hline $60.222 *$ & $-3.562 *$ & $-8.595^{*}$ \\
\hline \multicolumn{3}{|c|}{ (8) } \\
\hline $88.488^{*}$ & $-6.507 *$ & $-12.353^{*}$ \\
\hline
\end{tabular}

The analysis of table (3) unveils that the domestic market size, proxied by real GDP, affects in a positive and significant in Forward and Backward, this finding points out that the size of the domestic market is likely to expand trade in value added for all countries upstream and downstream side. The result is consistent with (Mouanda G. and Gong J. 2019), (de Melo J. and Twum A. 2020). So We accept the H1: The GVC forward and backward is positively associated with GDP.

FDI has a positive and significant sign on GVCs forward and backward; Due to major cross-border investments in extractive industries by TNCs. The result is consistent with (Kowalski et al., 2015), (Lopez Gonzalez 2016), (Tinta A., 2017), (Mouanda G. and GongJ. 2019). So We accept the H3: FDI stock is positively associated with GVCb and GVCf.

The access to domestic credit is positive and non significant for GVCf, and negative but not significant for GVCb. The finding reveals that the domestic banking industry in 
MENA countries does not play a vital role in promoting GVCs participation. The result is consistent with (Mouanda G. and Gong J., 2019). So we reject the H4: The GVCf and GVCb is positively associated with access to domestic credit.

The degree of industrialization impacts adversely and significantly in forward and backward GVCs. This empirical evidence shows that the industrialization level is very low, the share of domestic value added to exports decreases as the degree of industrialization decrease. The MENA countries still in the primary stage of economic development, depended on extractive industry, and principal products which work as inputs or raw materials into production processes. This result consistent with (Tinta A. 2017), (Mouanda G. and Gong J. 2019).So we reject the hypothesis H2: The Manufacturing share in GDP is positively associated with GVCf, and GVCb.

The quality of overall infrastructure affects positively but significantly in use internet and mobile that means communication infrastructure play vital role in forward and backward GVC, Quality of roads significant only in backward participation, Quality of ports don't have any effect, This result suggests that as the quality of overall infrastructure improves, MENA countries are likely to increase their participation in domestic value added to exports towards direct and indirect trading partners. The result is consistent with (de Melo J. and Twum A. 2020. Kevin Cheng, et al 2015, Mouanda G. and Gong J. 2019). So we accept the H5: The GVCf, and GVCb is positively associated with the Quality of Infrastructure.

Unlike the positive effect of overall infrastructure, we observe that institutional quality indicatoes (political stability, rlole of law, control of coruption) and Intellectual property rights protection tends to shrink the engagement in GVC participation for MENA countries. Indeed, the average quality of institutions among the sampled economies is relatively low; as it suffers from political instability, and therefore represents a barrier to participation in international fragmentation of production. The result is consistent with (Mouanda G. and 
Gong J .2019). So we reject the hypothesis H6: The GVCf, and GVCb is positively associated with the Quality of Institutions.

The measure of Innovation is positively and significant in forward linkage, while no significant on backward participation. This is due to the low level of the manufacturing industry that contains a high level of technology because the level of the industry depends more on the extractive industry. On the whole, we notice that the higher the percentage of innovation the higher the participation in forward and backword GVC. So we accept the hypothesis H7: The GVCf, and GVCb is positively associated with high Innovation.

\section{7- Conclusion and Recommendations}

This paper provides details about MENA Countries GVC participation over the period 2007-2018 with those for 15 countries. This helps us measure the predictions and challenges for MENA to increase contribution in supply chains trade.

MENA countries can now engage in supply chain trade in both backward (importing components/intermediates) and forward(selling components/intermediates that are manufactured further before reaching the consumer). MENA countries no longer have to construct whole factories from the ground up in order to industrialize.

MENA countries mostly participate in the upstream phases, which usually include low value-added operations. Manufacturing has seen the most growth in backward participation, especially in the 'light manufacturing': "manufacturing machinery and transport equipment" and "electrical equipment". While agriculture, Mining, and Quarrying, are accompanied by Petroleum, Chemical, and NonMetallic Mineral Products, which have higher levels of forward participation. The results table (5) shows that the region has not 
been able to fully integrate into global production networks, and there are many challenges faces MENA countries.

Table (5) Main Results

\begin{tabular}{lll}
\hline variables & GVCb & GVCf \\
\hline GDP & $+\sqrt{ }$ & $+\sqrt{ }$ \\
FDI & $+\sqrt{ }$ & $+\sqrt{ }$ \\
DC & - & + \\
MVA & $-\sqrt{ }$ & $-\sqrt{ }$ \\
Quality of Infrastructure & $+\sqrt{ }$ & $+\sqrt{ }$ \\
Quality of Institutions & $-\sqrt{ }$ & $-\sqrt{ }$ \\
Innovations relationship, $\sqrt{\text { mean significant }}$ & $+\sqrt{ }$ \\
+,- mean positive, negative relation. & +
\end{tabular}

The results show GDP, FDI positively and significant effect on GVC participation. While the domestic banking industry in MENA countries does not play a vital role in promoting backward GVC participation. And the industrialization level is very low. Unlike the positive effect of overall infrastructure, we observe that institutional quality and Intellectual property rights protection tends to shrink the engagement in GVC participation for MENA countries. Finally, the measure of Innovation is positive and significant in forward linkage, while no significant on backward participation.

In order for GVCs to have a positive effect on productivity and competitiveness, the MENA countries should: *Attractive more FDI stock and directing it towards manufacturing industries to promoting GVC participation.

* Improvement the role of banks to supporting SMEs, that can promoting GVC participation.

* Increase the value add of manufacturing in GDP.

* Improvement of quality of overall infrastructure.

*Improvement in institutional quality and Intellectual property rights protection. 
* Enhancing human capital development and taking steps to foster innovation and $\mathrm{R} \& \mathrm{D}$.

\section{References:}

Allard, C. et al., 2016, Trade Integration and Global Value Chains in Sub Saharan Africa: In Pursuit of the missing link, Departmental Paper No. 16/05, African Department, IMF.

Anderson, J. E. and E. Van Wincoop, 2003, Gravitas: A Solution to the Broder Puzzle, The American Economic Review, 93(1).

Anderson, J. E. 1979, A Theoretical Foundation for the Gravity Equation, The American Economic Review, 69(1).

Baldwin, J., and B. Yan, 2014, Global Value Chains and the Productivity of Canadian Manufacturing Firms, Economic Analysis Research Paper Series (Ottawa, statistics Canada).

Baldwin, R. 2009, Integration of the North American Economy and New Paradigm Global isation, CEPR Discussion Paper Series, No. 7523.

Baldwin, R. 2012, Trade and Industrialization after Globalization's Second Unbundling: How Building and Joining a Supply Chain Are Different and Why it matters, in Globalization in an Age of Crisis: Multinational Economic Cooperation.

Baltagi, B. 2005, Economic Analysis of Panel Data, Third Edition, J. Wiley.

Bamber, P., L.et al., 2014, Connecting Local Producers in Developing Countries to Regional and Global Value Chains: Update, OECD Trade Policy. Papers, No. 160, OECD Publishing.

Blanchard, E., 2013, What Global Fragmentation Means for the WTO: Article XXIV, Beging-the-Broder Concessions, and A New Case for WTO Limits on Investment 
Incentives, WTO Working Paper ERSD-2013-03 (Geneva: World Trade Organization).

Blvde, J.S., 2014, Synchronized Factories; Latin America and the Caribbean in the Era of Global Value Chains, Springer.

Carlo Pietrobeli and Roberta Rabellotti , 2011, Global Value Meet Innovation Systems: Are There Learning Opportunities for Developing Countries? World Development Vol. 39, No. 7.

Chor, D.,2010, Unpacking Sources of Comparative Advantage: A quantitative Approach", Journal of International Economics, .82.

Costinot, A. ,2009, On the Origins of Comparative Advantagel, Journal of International Economics, 77.

Davide Del Prete et al., 2016, Global Value Chains Participation and Productivity Gains for North Africa Firms, CENTRO STUDI LUCA D'AGLIANO DEVELOPMENT STUDIES WORKING PAPERS, N. 407, ISSN 2282-5452.

Escaith, H. ,2014, "Exploring the policy dimensions of trade in value- added", MPRA Paper, No. 59891, University of Munich, Germany.

Evenett, S. J. and W. Keller, 2002, On Theories Explaining the Success of the Gravity Equation, Journal of Political Economy, 110(2).

Gereffi, G., j. et al., 2001, Global isation, Value Chains and Development, IDS Bulletin, 32 (3).

Hausmann R. 2014, In Search of Convergence, Project Syndicate.

Hummels, D. 2001, Time as a Trade Barrier", GTAP Working papers, No 1152, Center for Global Trade Analysis, Department of Agricultural Economics, Purdue University.

Hummels D.., and Schaur, G., 2012, "Time as a Trade Barrier". NBER Working Paper No. 17758 (Cambridge, 
Massachusetts: National Bureau for Economic Research).

Hummels, D., J. Isahii, and $\mathrm{k}-\mathrm{M}$. Yi, 2001, The nature and growth of vertical specialization in the world trade, Journal of International Economics, 54(1).

Inoue Hiroyasu and TodoYasyuki, 2020, The propagation of economic impacts through supply chains: The case of a mega-city lockdown to prevent the spread of COVID-19, RIETI Discussion Paper series.

DdeMelo. J and Twum A., 2020, Supply Chain trade in East Africa:Prospects and Challenges, international growth center, F-19103.

Hebatallah A. Soliman, 2020, The Impact of Port Efficiency on Bilateral Trade between Egypt and African Countries, Scientific journal for economic\& commerce, Faculty of commerce, Ain Shams university

Vol50(1). https://jsec.journals.ekb.eg/article_96216.html.

Kevin Cheng, et al, 2015, Reaping the Benefits from Global Value Chains, IMF Working Paper, WP/15/204.

Koopman R., et al., 2011, Give Credit Where Credit Is Due: Tracing Value Added in Global Production Chains, NBER Working paper.

Kowalski, P. et al., 2015, Participation of Developing Countries in Global Value Chains: Implications for Trade and Trade-Related Policies, OECD Trade Policy Papers, No. 179, OECD Publishing Paris.

Kowalski, P., 2011, Comparative Advantage and Trade Performance: Policy Implications, OCED Trade Policy Working Papers, No. 121.

Kummritz, V., Taglioni, D., Winkler, D., 2017, Economic Upgrading through Global Value Chain Participation: Which Policies increase the value added gains, Policy Research Working Paper No. 8007.

Levchenko, A. A., 2007, Institutional Quality and International Trade. Review of Economic Studies, 74(3). 
Lopez Gonzalez., J., 2016, Using Foreign Factors to Enhance Domestic Export Performance: A Focus on Southeast Asia, OECD Trade Policy Papers, No. 191, OCED Publishing, Paris.

Lopez-Gonzalez, J.,2012, Vertical Special isation and New Regionalism, $\mathrm{PhD}$ thesis (Brighton: University of Sussex).

Markus H., Jean-Paul R., 2006, Global Production networks and the role of logistics and transportation", growth and change, 37 (4).

Miroudot, S. and A. Ragoussis , 2009, Vertical Trade, Trade costs and FDI, OECD Trade Policy Paper, No. 89, OCED Publishing.

Mounada G and Gong J., 2019.,Determinants of global value chains for landlocked countries, International Journal of Social Sciences and Economic Research ISSN: 24558834, 4(5).

Nunn, N.,2007,- Relationship-Specificity, Incomplete Contracts and the Pattern of Trade, Quarterly Journal of Economics, 122.

OECD, 2013, Interconnected Economies: Benefiting from Global Value Chains, OECD Publishing, Paris.

OECD, UNCTAD, and WTO, 2013, "Implications of Global Value Chains for Trade, Investment, Development and Jobs". OECD, Paris.

Primo Braga, C. A., 2013, Globalization in the $21^{\text {st }}$ century: The Role of Global Value Chains, IMD, Lausanne.

R. Maria et al., 2020, Supply and demand shocks in the COVID19pandemic: An industry and occupation perspective.

Ramesh Chandra, 2004, Adam Smith, Allyn Young, and the Division ofLabor, Journal of Economic Issue, Vol. 38(3).

Richard Pomfret, 2020, Global Production Networks, New Trade Technologies and the Challenges for International Institutions, Foreign Trade Review, 55(1).

Rincon- Aznar, et al., 2020, Global Value Chains and economic dislocations: introduction, National Institute of 
Economic and Social Research, 2020. DOI: 10. 1017/nie. 2020. 13.

Sachs, J., 1998, "International Economics: Unlocking the Mysteries of Globalization", Foreign Policy, No. 110, Special Edition: Frontier of knowledge (spring, 1998).

Stamm, A. , 2004, Value Chains for Development Policy, Challenges for Trade Policy and the Promotion of Economic Development, Deutscheg essellschaftfur Techniscje Zusammenarbeit, Eschborn.

Tinta, A. A., 2017, “ The determinants of participation in global value chains: The case of ECOWAS", Cogent Economies \& Finance, 5

UNCTAD, 2014, Trade and Development Report 2014, United Nations, New York and Geneva.

UNCTAD-Eora, (2019), Global Value Chain Dtatbase, https://worldmrio.com/unctadgvc.

World Bank, 2020, Trading for Development in the age of global value chains, world develomenet report, The Development in the age of global value chains, world development report, The World Bank, Washington.

WTO, 2014, World Trade Report, "The Rise of Global Value Chains. 
